\title{
Rekomendasi teknik analisis citra SEM dengan menggunakan free software ImageJ
}

\author{
Neng Nenden Mulyaningsih ${ }^{1}$, Fita Widiyatun $^{2}$, Sri Endang Wahyuni ${ }^{2}$ \\ ${ }^{1}$ Program Studi Pendidikan Fisika, Fakultas Matematika dan Ilmu \\ Pengetahuan Alam, Universitas Indraprasta PGRI, Jakarta - Indonesia \\ ${ }^{2}$ Program Studi Informatika, Fakultas Teknik dan Ilmu Komputer, Universitas In- \\ draprasta PGRI, Jakarta - Indonesia \\ * Corresponding author. E-mail: nengnendenmulyaningsih@gmail.com (Neng Nenden \\ Mulyaningsih), \\ Telp: +62-21-87797409, Fax: +62-21-87781300
}

\begin{abstract}
ABSTRAK
Citra scanning electron microscope (SEM) telah diketahui dapat menghasilkan informasi data morfologi baik secara kualitatif maupun kuantitatif dari suatu sampel dalam skala mikro. Oleh karena itu diperlukan teknik analisis yang tepat dalam mengolah citra SEM untuk mendapatkan data yang akurat. Tujuan dari penelitian yang sudah dilakukan yaitu untuk mendapatkan teknik analisis citra SEM dengan menggunakan free software ImageJ. Citra SEM dari serat agave yang sudah diberi perlakuan dengan perendaman dalam larutan natrium hidroksida $(\mathrm{NaOH})$ 5\% selama 30 menit diambil tiga variasi perbesaran yaitu 250x, 500x dan 1000x. Parameter yang dianalisis berupa bentuk dan ukuran region of interest (ROI), nilai rata-rata dan penyimpangan pixel. Bentuk ROI yang dipilih yaitu rectangular, elliptical dan freehand, sementara ukuran ROI-nya masing-masing 100.000, 50.000 dan 25.000 pixel. Hasil analisis menunjukkan bahwa citra SEM dengan perbesaran 1000x pada ROI model freehand dengan ukuran 25.000 pixel mempunyai persentase standar deviasi yang paling rendah (9,325\%). Kesimpulannya dalam menganalisis citra SEM dengan menggunakan aplikasi free software ImageJ direkomendasikan memilih gambar dengan perbesaran paling tinggi, bentuk ROI freehand dan ukuran ROI paling kecil.
\end{abstract}

Kata Kunci : Citra SEM; ImageJ; Region of interest; Serat agave 


\begin{abstract}
Scanning electron microscope (SEM) images are known to produce morphological data information both qualitatively and quantitatively from a sample on a micro scale. Therefore we need the right analysis technique in processing SEM images to obtain accurate data. The purpose of the research that has been done is to obtain SEM image analysis techniques using the ImageJ free software. SEM images of agave fibers that have been treated by immersion in 5\% sodium hydroxide $(\mathrm{NaOH})$ solution for 30 minutes were taken three variations of magnification, namely $250 \mathrm{x}$, 500x and 1000x. The parameters analyzed were the shape and size of the region of interest (ROI), the average value and the pixel deviation. The ROI shapes chosen are rectangular, elliptical and freehand, while the ROI sizes are 100,000, 50,000 and 25,000 pixels, respectively. The analysis results show that the SEM image with 1000x magnification on ROI freehand model with a size of 25,000 pixels has the lowest standard deviation percentage (9.325\%). In conclusion, in analyzing SEM images using the Image J free software application, it is recommended to choose the image with the highest magnification, freehand ROI form and the smallest ROI size.
\end{abstract}

Keywords : SEM image; ImageJ; Region of interest; Agave fiber

\section{Pendahuluan}

Image J adalah program pemrosesan gambar berbasis Java yang dikembangkan di oleh Peneliti di Research Services Branch, National Institute of Mental Health, Bethesda, Maryland, USA. Penggunaan Image-J dalam analisis gambar digital telah digunakan secara luas dalam bidang kesehatan dan biologi bahkan dalam bidang fisika $[1,2]$. ImageJ dirancang dengan arsitektur terbuka yang menyediakan ekstensibilitas melalui plugin Java dan makro yang dapat direkam [3,4]. Akuisisi kustom, analisis dan pemrosesan plugin dapat dikembangka menggunakan editor bawaan ImageJ dan kompiler Java $[5,6]$. Plugin yang ditulis pengguna memungkinkan untuk menyelesaikan banyak masalah pemrosesan dan analisis gambar, mulai dari pencitraan sel langsung tiga dimensi hingga pemrosesan gambar radiologis, beberapa perbandingan data sistem pencitraan hingga sistem hematologi otomatis. Arsitektur plugin ImageJ dan lingkungan pengembangan bawaan telah membuatnya menjadi platform yang populer untuk mengajarkan pemrosesan gambar [7]. 
Meskipun suatu gambar atau citra dapat memberikan informasi terhadap hasil penelitian, namun adakalanya suatu citra yang kita hasilkan mempunya mutu yang kurang bagus (mengalami degradasi), misalnya mengandung cacat atau adanya noise (derau), warnanya terlalu kontras, kurang tajam, kabur (blurring) atau karena faktor lainnya. Hal-hal tersebut dapat mengakibatkan sulitnya dalam menginterfretasi informasi yang terkandung dalam suatu citra, sehingga diperlukan teknik khusus atau bantuan alat lain untuk menggali informasi yang terkandung dalam suatu citra, salah satunya yaitu dengan menggunakan software ImageJ.

Telah banyak penelitian sebelumnya yang menggunakan software ImageJ dalam menganalisis suatu gambar, seperti analisis neurohistologi [8], analisis fase kontras dari gambar TEM dan analisis struktur tulang ikan zebra $[9,10]$. Namun penelitian-penelitian tersebut lebih fokus terhadap karakter dari sampel yang digunakan dalam penelitiannya. Masih sulit ditemukan penelitian yang mengkaji lebih dalam terkait dengan teknik analisis dengan software ImageJ. Oleh karena itu, fokus penelitian ini yaitu membahas teknik dalam menganalisis suatu gambar atau citra dari suatu sampel dengan menggunakan software ImageJ.
Jadi, tujuan utama dari penelitian ini adalah untuk mendapatkan teknik yang paling tepat dalam menganalisis susatu citra atau gambar sehingga diperoleh informasi yang paling sesuai, baik secara kuantitatif maupun secara kualitatif. Tujuan kami adalah untuk menunjukkan rekomendasi yang paling tepat dan praktis dalam pengolahan suatu gambar. Studi kasus pada sampel serat agave yang diberi perlakuan perendaman dalam larutan natrium hidroksida $(\mathrm{NaOH})$ 5\% selama 30 menit, kemudian dikarakterisasi dengan scanning electron microscope (SEM).

\section{Bahan dan Metode}

\subsection{Persiapan sampel}

Penelitian ini merupakan penelitian eksperimen dengan menggunakan sampel dari hasil penelitian Widiyatun, et al. [11]. Sampel berupa serat agave yang diberi perlakuan dengan perendaman dalam larutan natrium hidroksida $(\mathrm{NaOH})$ 5\% selama 30 menit, kemudian dicuci dengan asam klorida encer $(\mathrm{HCl})$ untuk menghilangkan kelebihan alkali. Serat tersebut dibilas dengan air dingin dua sampai tiga kali. Setelah dibilas, serat dikeringkan pada suhu kamar selama 2-3 hari. Selanjutnya sampel serat agave dikarakterisasi dengan SEM. 


\subsection{Karakterisasi Sampel dengan SEM}

Sampel serat agave diambil gambaran morfologinya dengan menggunakan scanning electron microscope (SEM) Hitachi S-3400N dengan tegangan 20 $\mathrm{kV}$ dan tekanan $65 \mathrm{~Pa}$. Dipilih tiga perbesaran yang berbeda masingmasing dengan perbesaran 250x (sampel A), 500x (sampel B) dan 1000x (sampel C).

\subsection{Pengolahan Citra SEM dengan software ImageJ}

Citra SEM yang dihasilkan dianalisis dengan bantuan software Image-J application (V 1.46r, NIH, USA) dan dievaluasi rata-rata pixelnya dengan menetukan region of interest (ROI) model rectangular, elliptical dan freehand. Pada masing-masing model ROI dianalisis pada tiga ukuran area yang berbeda yaitu 100.000 pixel, 50.000 pixel dan 25.000 pixel.

\subsection{Analisis Statistik}

Nilai rata-rata, standar deviasi dan interval kepercayaan diukur untuk semua kelompok sampel. Kami menggunakan uji t berpasangan untuk menganalisis nilai rata-rata pixel dan ukuran pixel dari citra serat agave. Semua data dianalisis menggunakan Statistical Package for Social Sciences (SPPS) V22.0. Nilai $\mathrm{P}<0,05$ dianggap berbeda signifikan.

\section{Hasil dan Pembahasan}

Citra SEM dari serat agave yang sudah direndam dalam larutan natrium hidroksida $(\mathrm{NaOH})$ 5\% selama 30 menit dengan perbesaran 250x, 500x dan 1000x ditunjukkan pada Gambar 1. Pada perbesaran 250x dan 500x masih terlihat adanya background. Hal ini akan menyebabkan ketidakakuratan dalam analisisnya. Pada perbesaran 1000x sudah tidak nampak adanya background, sehingga pada perbesaran ini kita akan lebih yakin bahwa citra yang dianalisis yaitu dari sampel yang digunakan. Hal ini juga didukung berdasarkan hasil analisis histogramnya seperti tampak pada Gambar 2.

Histogram pada Gambar 2.a tampak lebih bergeser ke area yang berwarna hitam, hal ini menunjukkan bahwa tingkat homogenitasnya rendah akibat adanya background. Gambar 2.b dan 2.c terlihat grafiknya mulai bergeser ke arah kanan, sehingga pada perbesaran yang lebih tinggi secara morfologi lebih jelas terlihat. Kondisi ini didukung pula oleh nilai standar deviasi dari rata-rata pixel untuk masing-masing perbesaran secara berturut-turut yaitu $(54,901 \pm 39,748)$, $(95,353 \pm 50,695)$ dan $(112,099 \pm$ 45,925).

Persentase standar deviasi dari citra dengan perbesaran 250x paling tinggi yaitu $72,39 \%$, standar deviasi dari citra dengan perbesaran 500x yaitu 53,17\%, 
dan standar deviasi dari citra dengan perbesaran 1000x yaitu 40,97\%. Citra dengan perbesaran 250x dan 500x mempunyai standar deviasi di atas 50\% sehingga akurasi analisisnya akan rendah, oleh karena itu yang lebih direkomendasikan yaitu citra dengan perbesaran 1000x.

Beberapa fasilitas yang tersedia pada software Image J di antaranya yaitu pemilihan model dalam analisis region of interest (ROI). Analisis ROI dilakukan pada gambar supaya lebih spesifik dan citra yang dianalisis lebih seragam. Nilai rata-rata pixel dengan ROI model rectangular disajikan pada Tabel 1 . Berdasarkan tabel tersebut terlihat bahwa perbandingan ukuran area antara 100.000 pixel, 50.000 pixel dan 25.000 pixel dari sampel A dan sampel B menunjukkan perbedaan yang signifikan pada nilai $\mathrm{P}<$ 0,05. Oleh karena itu jika kita menggunakan sampel A maka hasil analisis yang diperoleh akan berbedabeda, sehingga validitasnya diragukan. Penelitian sebelumnya juga menyatakan bahwa pada perbesaran yang kecil, maka ukuran partikel juga tampak lebih kecil [12]. Sementara pada sampel C untuk ukuran area 100.000 pixel dan 50.000 pixel sudah menunjukkan nilai yang relatif konstan, akan tetapi pada ukuran area 25.000 pixel masih menunjukkan perbedaan yang nyata. Persentase penyimpangan terendah dihasilkan dari sampel C dengan area ROI 25.000 pixel yaitu sebesar $17,863 \%$.

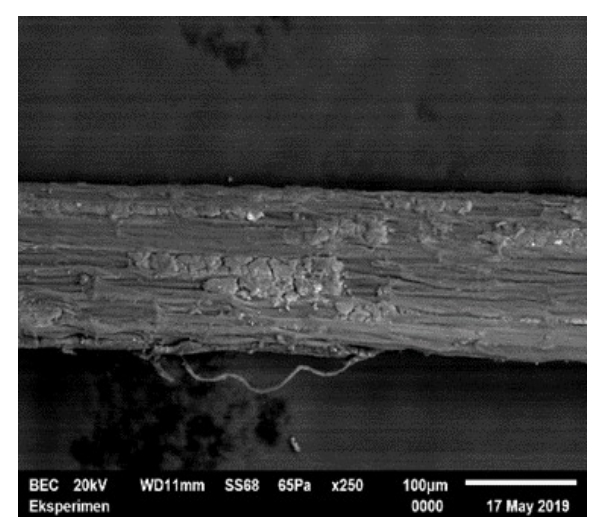

(a)

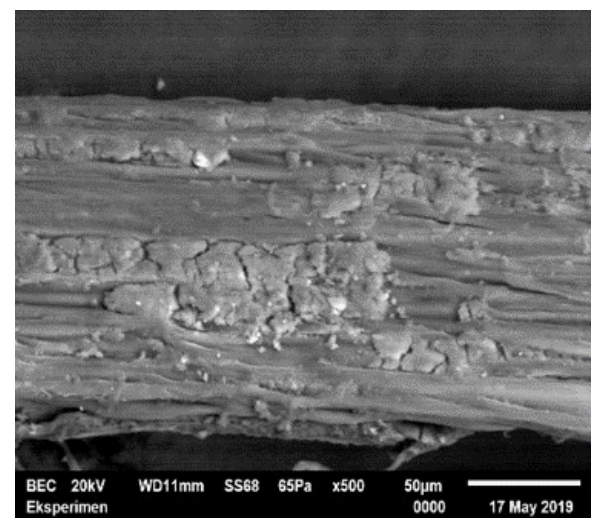

(b)

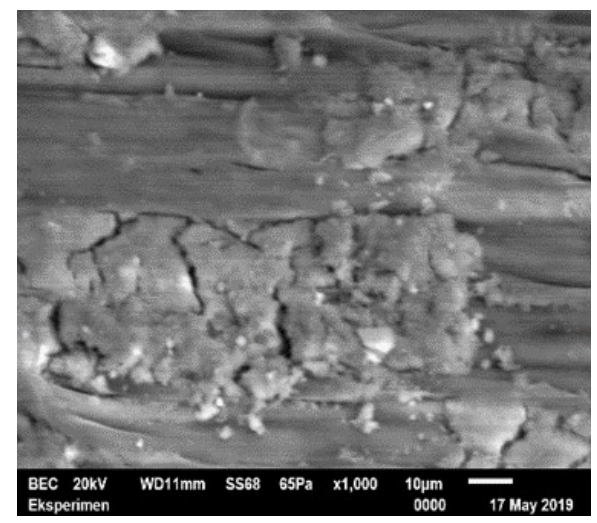

(c)

Gambar 1. Citra SEM dari serat agave yang sudah direndam dalam larutan natrium hidroksida (NaOH) 5\% selama 30 menit, (a) perbesaran 250x, (b) perbesaran 500x dan (c) perbesaran 1000x. 


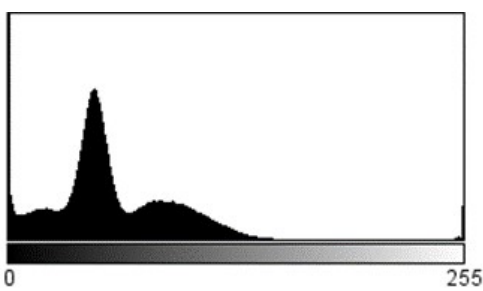

Count: $1228800 \quad$ Min: 0

Mean: 54.901

StdDev: 39.748

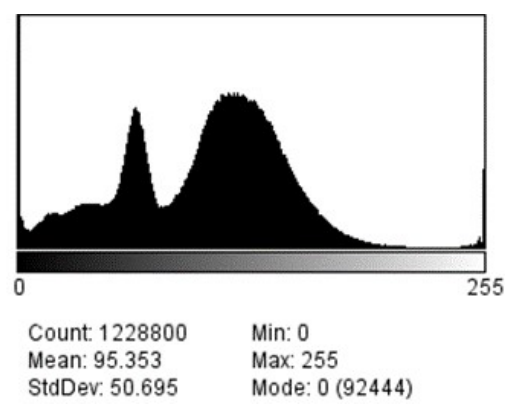

(b)

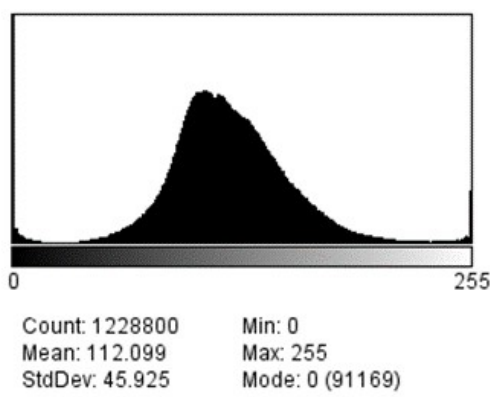

(c)

Gambar 2. Histogram citra SEM dari serat agave yang sudah direndam dalam larutan natrium hidroksida $(\mathrm{NaOH})$ 5\% selama 30 menit, (a) histogram citra SEM perbesaran 250x, (b) histogram citra SEM perbesaran 500x dan (c) histogram citra SEM perbesaran 1000x.

Tabel 1. Rata-rata pixel dengan ROI rectangular selections

\begin{tabular}{cccc}
\hline \multirow{2}{*}{ Area } & \multicolumn{3}{c}{ Sampel } \\
\cline { 2 - 4 } & $\mathrm{A}$ & $\mathrm{B}$ & $\mathrm{C}$ \\
\hline 100.000 Pixel & $97,575 \pm 31,525$ & $139,010 \pm 35,160$ & $130,465 \pm 27,795$ \\
Persentase SD & $32,308 \%^{\mathrm{a}}$ & $25,293 \%^{\mathrm{b}}$ & $21,305 \%^{\mathrm{c}}$ \\
50.000 Pixel & $99,197 \pm 27,983$ & $142,621 \pm 32,294$ & $127,306 \pm 26,941$ \\
Persentase SD & $28,209 \%^{\mathrm{b}}$ & $22,643 \%^{\mathrm{d}}$ & $21,162 \%^{\mathrm{c}}$ \\
25.000 Pixel & $111,449 \pm 29,209$ & $141,020 \pm 28,622$ & $129,144 \pm 23,069$ \\
Persentase SD & $26,208 \%{ }^{\mathrm{c}}$ & $20,296 \% \mathrm{o}^{\mathrm{e}}$ & $17,863 \%^{\mathrm{f}}$ \\
\hline
\end{tabular}

Keterangan: Perbedaan yang nyata $(\mathrm{P}<0,05)$ ditandai dengan penulisan superskrip huruf kecil yang berbeda pada baris dan kolom yang sama

A: citra SEM dengan perbesaran 250x

B: citra SEM dengan perbesaran 500x

C: citra SEM dengan perbesaran 1000x

SD: Standar deviasi 
Tabel 2. Rata-rata pixel dengan ROI elliptical selections

\begin{tabular}{cccc}
\hline \multirow{2}{*}{ Area } & \multicolumn{3}{c}{ Sampel } \\
\cline { 2 - 4 } & $\mathrm{A}$ & $\mathrm{B}$ & $\mathrm{C}$ \\
\hline 100.000 Pixel & $96,740 \pm 25,647$ & $137,868 \pm 30,337$ & $111,354 \pm 25,321$ \\
Persentase SD & $26,511 \%^{\mathrm{a}}$ & $22,004 \%^{\mathrm{b}}$ & $22,739 \%^{\mathrm{b}}$ \\
50.000 Pixel & $101,034 \pm 25,437$ & $144.694 \pm 31,015$ & $140,122 \pm 29,489$ \\
Persentase SD & $25,177 \%^{\mathrm{a}}$ & $21,435 \%{ }^{\mathrm{b}}$ & $21,045 \%{ }^{\mathrm{b}}$ \\
25.000 Pixel & $110,345 \pm 25,276$ & $134,027 \pm 27,657$ & $134,049 \pm 23,430$ \\
Persentase SD & $22,906 \%^{\mathrm{b}}$ & $20,635 \%{ }^{\mathrm{c}}$ & $17,479 \%{ }^{\mathrm{d}}$ \\
\hline
\end{tabular}

Keterangan: Perbedaan yang nyata $(\mathrm{P}<0,05)$ ditandai dengan penulisan superskrip huruf kecil yang berbeda pada baris dan kolom yang sama

A: citra SEM dengan perbesaran 250x

B: citra SEM dengan perbesaran 500x

C: citra SEM dengan perbesaran 1000x

SD: Standar deviasi

Tabel 3. Rata-rata pixel dengan ROI freehand selections

\begin{tabular}{cccc}
\hline \multirow{2}{*}{ Area } & \multicolumn{3}{c}{ Sampel } \\
\cline { 2 - 4 } & $\mathrm{A}$ & $\mathrm{B}$ & $\mathrm{C}$ \\
\hline 100.000 Pixel & $97,994 \pm 24,815$ & $137,123 \pm 28,632$ & $131,885 \pm 27,447$ \\
Persentase SD & $25,512 \%^{\mathrm{a}}$ & $20,881 \%^{\mathrm{c}}$ & $20,811 \%^{\mathrm{c}}$ \\
50.000 Pixel & $106,034 \pm 24,437$ & $142.874 \pm 28,815$ & $140,281 \pm 19,915$ \\
Persentase SD & $23,046 \%^{\mathrm{b}}$ & $20,168 \%^{\mathrm{c}}$ & $14,197 \%{ }^{\mathrm{d}}$ \\
25.000 Pixel & $107,626 \pm 25,225$ & $137,098 \pm 26,111$ & $144,749 \pm 13,498$ \\
Persentase SD & $23,438 \%{ }^{\mathrm{b}}$ & $19,046 \%{ }^{\mathrm{c}}$ & $9,325 \%{ }^{\mathrm{e}}$ \\
\hline
\end{tabular}

Keterangan: Perbedaan yang nyata $(\mathrm{P}<0,05)$ ditandai dengan penulisan superskrip huruf kecil yang berbeda pada baris dan kolom yang sama

A: citra SEM dengan perbesaran 250x

B: citra SEM dengan perbesaran 500x

C: citra SEM dengan perbesaran $1000 \mathrm{x}$

SD: Standar deviasi 
Nilai rata-rata pixel dengan ROI model elliptical disajikan pada Tabel 2. Persentase standar deviasi yang diperoleh dari ROI model elliptical cenderung lebih rendah dibandingkan dengan model rectangular, sehingga analisis dengan model elliptical akan menghasilkan informasi yang lebih tepat karena sebaran sampelnya lebih homogen. Disamping model rectangular dan model elliptical juga terdapat model freehand, model ini bisa dibuat bentuk bebas sesuai dengan keinginan peneliti. Hasil analisis model freehand disajikan pada Tabel 3.

Berdasarkan Tabel 3, persentase standar deviasi terlihat lebih rendah pada kelompok sampel C. Ukuran pixel yang semakin kecil juga menunjukkan persentase standar deviasi yang semakin menurun juga. Jika dibandingkan dengan hasil analisis dengan menggunakan ROI model rectangular dan model elliptical, maka model freehand mempunyai persentase nilai standar deviasi yang paling rendah. ROI model freehand lebih memungkinkan pemilihan area tertentu untuk dievaluasi dan membiarkan area yang tidak diinginkan $[13,14]$.

Hasil dari penelitian sudah jelas menunjukkan bahwa metode pengolahan citra SEM dari serat agave dengan menggunakan software Image J yang paling baik yaitu dari sampel C (citra SEM dengan perbesaran 1000x) pada ROI model freehand dengan ukuran 25.000 pixel. Oleh karena itu, paling baik menggunakancitra sampel yang mempunyai perbesaran tinggi tetapi area ROI yang kecil. Dengan begitu citra sampel akan terlihat lebih jelas namun tetap homogen, sehingga hasil analisis yang diperoleh akan lebih teliti.

Teknik ROI memiliki keunggulan dalam pengolahan citra yaitu sampel yang dianalisis adalah sampel pilihan, tetapi teknik ini mempunyai kekurangan karena hasilnya subyektif dan tergantung kepada kemampuan analisator. Rekomendasi untuk penelitian selanjutnya yaitu perlu dilakukan analisis citra dengan aplikasi yang lainnya seperti MicroView untuk menguji kecocokan dari teknik analisis dengan ImageJ. Selain itu citra yang dianalisis juga tidak terbatas pada citra hasil karakterisasi dengan SEM, melainkan bisa dicoba pada citra yang lainnya seperti kasil karakterisasi dengan transmission electron microscopy (TEM).

\section{Simpulan}

Berdasarkan hasil analisis terhadap citra SEM dari serat agave yang diberi perlakuan perendaman dalam larutan natrium hidroksida $(\mathrm{NaOH}) 5 \%$ selama 30 menit dengan menggunakan software ImageJ diperoleh teknik analisis yang paling baik yaitu dengan menggunakan gambar pada perbesaran paling tinggi, bentuk ROI freehand dan ukuran region of interest (ROI) paling kecil. 


\section{Referensi}

1. Rueden, C.T., Schindelin, J., Hiner, M.C., DeZonia, B.E., Alison E. Walter, A.E., Arena, E.T., Eliceiri, K.W. (2017). ImageJ2: ImageJ for the next generation of scientific image data. BMC Bioinformatics, 18: 529.

2. Valente, A.J., Maddalena, L.A., Robb, E.L., Moradi, F., Stuart, J.A. (2017). A simple ImageJ macro tool for analyzing mitochondrial network morphology in mammalian cell culture. Acta Histochemica, 119: 315-326.

3. Schneider, C.A., Rasband, W.S., Eliceiri, K.W. (2012). NIH image to ImageJ: 25 years of image analysis. Nat. Methods, 9: 671.

4. Patel, A., Li, Z., Canete, P., Strobl, H., Dulin, J., Kadoya, K., Gibbs, D., Poplawski, G.H.D. (2018). AxonTracer: a novel ImageJ plugin for automated quantifcation of axon regeneration in spinal cord tissue. BMC Neuroscience, 19: 8

5. Wendykier, P., Nagy, J.G. (2010). Parallel colt: a high-performance Java library for scientific computing and image processing. ACM Trans. Math. Software, 37: 1-22.

6. Igathinathane, C., Pordesimo, L.O., Columbus, E.P., Batchelor, W.D., Methuku, S.R. (2008). Shape identification and particles size distribution from basic shape parameters using ImageJ. Comp. Electr. Agricult., 63: 168-182.

7. Timothy, M., Forlano, P.M. (2019). A versatile macro-based neurohistological image analysis suite for ImageJ focused on automated and standardized user interaction and reproducible data output. $J$. of Neurosci. Methods, 324: 108286.

8. Amandine, V., Cédric, M., Sergio, M., Patricia D. (2019). An ImageJ tool for simplified post-treatment of TEM phase contrast images (SPCI). Micron, 121: 9098.

9. Tarasco, M., Cordelières, F.P., Cancela M.L., Laizé, V. (2020). ZFBONE: An ImageJ toolset for semi-automatic analysis of zebrafish bone structures. Bone, 138: 115480.

10. Torre, I.G., Heck, R.J., Tarquis, A.M. (2020). MULTIFRAC: An ImageJ plugin for multiscale characterization of $2 \mathrm{D}$ and 3D stack images. SoftwareX, 12: 100574.

11. Widiyatun, F., Mulyaningsih, N.N., Dwitiyanti, N. (2019). Analisis gugus fungsi dan morfologi serat agave dengan FTIR dan SEM. Laporan penelitian Dipa Unindra Tahun 2019 No:0357/SP3/KP/LPPM/ UNINDRA/III/2019.

12. Kurniawan, C., Waluyo, T.B., Sebayang, P. (2011). Analisis ukuran partikel menggunakan free software Image-J. Seminar Nasional Fisika, Pusat Penelitian Fisika-LIPI, Serpong, 12-13 Juli 2011

13. Girish, V., Vijayalakshmi, A. (2004). Affordable image analysis using $\mathrm{NIH}$ Image/ImageJ. Indian Journal Cancer, 41: 47.

14. Jensen, E.C. (2013). Quantitative analysis of histological staining and fluorescence using ImageJ. Anatomic. Record, 296: 378381.parameters using ImageJ. Comp. Electr. Agricult., 63: 168-182. 